doi: 10.17492/vision.v2i2.10180

\title{
Infrastructure Development in India and the Role of Tax Incentives
}

\author{
Niti Bhasin*
}

\begin{abstract}
The demand for infrastructural services has increased rapidly after industrial liberalisation of the Indian economy. Recent years have witnessed substantial progress from the old paradigm of public monopoly provision of infrastructure services to the new paradigm which also encourages private investment and provision of infrastructure services within a stable, predictable and commercially viable regulatory framework. The case for attracting FDI is also significantly strengthened through the provision of an adequate level of infrastructure. There is thus adequate economic rationale for encouraging the sponsorship of infrastructure projects and to facilitate investments in this sector. In this context, the provision of fiscal benefits implies a contribution from government that is supported by benefits accruing from the externalities of the project. In the absence of such contribution, the private investment flows may not take place at all. This paper looks at the types of tax incentives being offered in the infrastructure sector that can contribute to mobilising private resources in the financing of projects.
\end{abstract}

Keywords: Infrastructure, Public private partnership, Tax incentives.

\subsection{Introduction}

Availability of adequate, efficient and affordable infrastructural facilities constitutes the core of development strategy and efforts. By their very nature, infrastructure projects (power, railways, ports, civil aviation, roads and telecommunications) involve huge initial investments, long gestation periods and high risk. The demand for infrastructural services has increased rapidly after industrial liberalisation of the Indian economy. Unfortunately, infrastructural bottlenecks remain the biggest stumbling block of industrial progress in the country. Recent years have witnessed substantial progress from the old paradigm of public monopoly provision of infrastructure services to the new paradigm which also encourages private investment and provision of infrastructure services within a stable, predictable and commercially viable regulatory framework.

*Associate Professor, Department of Commerce, Delhi School of Economics, University of Delhi. 
In the context of the emerging economic environment, the Economic Survey, 20002001 observed, "With greater demand, changing technology, increasing complexity for financing the infrastructure projects and the budgetary constraints the public sector is no longer able to discharge efficiently its role as a provider of infrastructure services. The Government has recognised that private sector participation including foreign investment is required to supplement the public sector efforts. Various reforms have been made in infrastructure sectors, and rules and procedures for investment have been liberalised in order to provide an enabling environment conducive for private participation."

The rest of the paper is organised as follows. Section 2 outlines some government initiatives with regard to infrastructure development. Section 3 explains the rationale of offering tax incentives in infrastructure along with some significant tax incentives being offered. Section 4 discusses the regulatory framework with regard to FDI in infrastructure and Section 5 concludes.

\subsection{India Infrastructure Finance Company Limited (IIFCL)}

IIFCL was incorporated on January 5, 2006 with a paid up capital of Rs. 10 crore and an authorized capital of Rs. 1,000 crore. Apart from its equity, IIFCL is funded through long-term debt raised from the open market. To enable the company to do so, the Government extends a guarantee for repayment of principal and interest. The extent of guarantee provided by Government of India in the first year of operations was Rs. 10,000 crore.

The setting up of IIFCL as a wholly owned Government company redeemed the promise made in the Budget Speech for 2005-06. There were many infrastructure projects which were financially viable but, in the current situation, faced difficulties in raising resources. It was proposed that such projects in specified sectors-roads, ports, airports and tourism — be funded through a financial Special Purpose Vehicle (SPV). The SPV would lend funds especially debt of longer term maturity, directly to the eligible projects to supplement other loans from banks and financial institutions Government communicates the borrowing limit to the SPV at the beginning of each fiscal year. For 2005-06, the borrowing limit was fixed at Rs. 10,000 crore.

IIFCL is a SPV created in keeping with the announcement made by the Finance Minister in his Budget Speech for the year 2005-06. The company renders financial assistance through the following channels:

a) Direct lending to eligible projects.

b) Refinance to banks and financial institutions (FIs) for loans with period of 5 years or more. 
c) Any other method approved by the Government of India.

The other salient features of infrastructure funding through the company are as under:

a) Loan assistance from SPV shall not exceed 20 percent of project cost.

b) A project awarded to a private sector company for development, financing, construction through PPP shall have overriding priority under the scheme.

c) Private sector companies will not be eligible for direct lending and only the refinancing option will be available in such cases. Further, the total lending to such projects will be kept within 20 percent of the lending programme of the IIFCL.

d) The rate of interest charged by IIFCL shall be such as to cover all fund costs including guarantee fee as well as administrative cost.

IIFCL is expected to be a very lean organization which would keep overheads to the minimum and thus keep the cost of funds for infrastructure at a competitive level. The company would fill the gap for long term infrastructure finance which the banks are not in a position to address owing to concerns relating to mismatches in assets and liabilities.

\subsection{Infrastructure Debt Funds (IDFs)}

Infrastructure projects are capital-intensive and have long payback periods, and, therefore, require long-term funds at comparatively low costs. Infrastructure projects in India are financed mainly by commercial banks, as insurance and pension funds do not normally lend for new projects. The present bond market lacks depth to address the needs for a long-term debt. With a view to overcoming these shortcomings, the Government has conceptualised IDFs for sourcing long-term debt for infrastructure projects. IDFs are being set up for channelising long-term debt from domestic and foreign pension and insurance funds, as well as from other sources. These IDFs will also carry adequate credit enhancement in terms of implicit government guarantees for repayment of debt. The Reserve Bank of India, and the Securities and Exchange Board of India have already laid down regulatory framework for the IDFs.

Besides augmenting debt resources for financing infrastructure, the IDFs would refinance PPP projects after their construction is completed and operations have stabilised. By refinancing bank loans of existing projects, the IDFs are expected to take over a significant volume of the existing bank debt, and this will release an equivalent volume of fresh lending for infrastructure projects.

Potential investors under IDFs may include off-shore institutional investors, offshore high net worth individuals (HNIs), and other institutional investors (insurance funds, pension funds, sovereign wealth funds etc.). An IDF can be set up either as a trust or as a non-banking financial company (NBFC). The income of IDFs has been exempted 
from income tax.

Broad guidelines were issued on September 23, 2011 for setting up IDFs to facilitate flow of funds into infrastructure projects. An IDF can be set up either as a trust or as a company. A trust-based IDF would normally be a mutual fund (MF), while a companybased IDF would normally be a Non-banking Financial Company (NBFC).

An IDF-NBFC would raise resources through issue of either rupee- or dollardenominated bonds of minimum 5-year maturity. The investors would be primarily domestic and off-shore institutional investors, especially insurance and pension funds which have long-term resources. An IDF-MF would be regulated by the Securities and Exchange Board of India (SEBI) while an IDF-NBFC would be regulated by the RBI.

Detailed guidelines were issued on November 21, 2011 prescribing the regulatory framework for NBFCs to sponsor IDFs which are to be set up as Mutual Funds (MFs) and NBFCs. Such entities would be designated as Infrastructure Debt Fund-Mutual Funds (IDF-MF) and Infrastructure Debt Fund-Non-banking Financial Company (IDF-NBFC). All NBFCs, including Infrastructure Finance Companies (IFCs) registered with the RBI may sponsor IDFs to be set up as MFs. However, only IFCs can sponsor IDF-NBFCs. Eligibility parameters for NBFCs as sponsors of IDF-MFs include the following:

1. Minimum net owned funds (NOF) of Rs. 300 crore.

2. CRAR of 15 percent.

3. Net NPAs less than 3 percent.

4. NBFC to have been in existence for at least 5 years and earning profits for the last 3 years in addition to those prescribed by SEBI in the newly inserted Chapter VIB to the MF Regulations.

5. Only NBFC-IFCs can sponsor IDF-NBFCs with prior approval of the RBI and subject to the following conditions: (a) Sponsor IFC would be allowed to contribute a maximum of 49 percent to the equity of the IDF-NBFC with a minimum equity holding of 30 percent of the equity of IDF-NBFC, post-investment, in the IDFNBFC, (b) Sponsor NBFC-IFC must maintain minimum CRAR and NOF prescribed for IFCs, (c) There are no supervisory concerns with respect to the IFC. The IDF is granted relaxation in credit concentration norms and in risk weights.

\subsection{Public Private Partnership (PPP) in Infrastructure}

There has been a huge gap in the demand and supply of essential social and economic infrastructures and services. These infrastructure shortages are key constraint in sustaining and expanding India's economic growth and making it more inclusive for the poor. Given the large resource requirements for investment and the budgetary constraints, Government of India has been encouraging private sector investment and 
participation in all sectors.

In India, Government is actively pursuing PPP to bridge the infrastructure deficit in the country. Several initiatives have been taken to promote PPP in sectors like power, ports, highways, airports, tourism and urban infrastructure. Under the overall guidance of the Committee of Infrastructure headed by the Prime Minister, the PPP programme has been finalised and the implementation of the various schemes is being closely monitored by the constituent Ministries/Departments under this programme. The appraisal mechanism for the PPP projects has been streamlined to ensure speedy appraisal of projects, remove red tape, adopt international best practices and have uniformity in guidelines.

An appraisal mechanism has been notified including the setting up of the Public Private Partnership Appraisal Committee (PPPAC) responsible for the appraisal of PPP projects in the central sector. The committee has mandated detailed guidelines for submitting proposals and follows a pre-determined time frame for according approval to proposals submitted in a time bound manner. Given the complex issues involved and the exposure of Government in such contracts, Committee on Infrastructure has mandated issue of model documents. Government has decided to create standardized frameworks based on due diligence rather than evolving agreements on a project-by-project basis. The agreements will be based on international practices and will create a framework with the right matrix of risk allocation obligations and returns. The Model Concession Agreement (MCA) for National Highways has been issued by the Committee on Infrastructure. Planning Commission has also issued MCAs for ports, state highways and operation and maintenance agreements for highways, though these are only for guidance and have not been approved by the Committee on Infrastructure.

PPP is still a nascent concept in India, and expertise at the level of project authorities, both at the central and state levels, is limited. The awareness of concerns and issues relating to PPP is still lacking and not evenly spread across the different States. A need was felt to provide capacity building in State Governments to enable them to prepare PPP proposals. To promote the PPP programme, all State Governments and Central Ministries have been advised to set up a PPP Cell with a senior level officer deputed as PPP nodal officer. It is proposed to provide assistance to states in this regard. Technical Assistance (TA) from the Asian Development Bank has been received for overall capacity building in State Governments for PPP. The TA would fund strengthening of the PPP Cell of the respective State governments, including hiring of consultants and training of personnel.

Future development of infrastructure will depend on how investment in infrastructure is facilitated. Such investment requires long-term funds with long pay back 
periods, for example, from insurance and pension funds. Thus, success on the infrastructure front will be facilitated by the development of a vibrant bond market, and pension and insurance reforms. A single, unified exchange-traded market for corporate bonds would help create a mature debt market for financing infrastructure.

\subsubsection{Recent PPP Initiatives in India}

Traditionally, infrastructure development used to occur through the public sector. However, given the scarcity of public resources, and the need to shift scarce public resources into health and education, efforts have been made to induct private participation in the development of infrastructure. These efforts have met with a fair degree of success. According to a report published by the World Bank, India has been the top recipient of PPP investment since 2006 and has accounted for almost half of the investment in new PPP projects implemented in the first half of 2011 in developing countries. An Asian Development Bank report states that India stands in the same league as developed economies like South Korea and Japan on implementation of PPP projects.

The Government of India is promoting public-private partnerships (PPP) as an effective tool for bringing private-sector efficiencies in creation of economic and social infrastructure assets and for delivery of quality public services.

Support for Project Development of PPP Projects: The India Infrastructure Project Development Fund (IIPDF) was launched in December 2007 to facilitate quality project development for PPP projects and ensure transparency in procurement of consultants and projects.

Cabinet Committee on Infrastructure: The approach to PPP must remain firmly grounded in principles which ensure that PPP are formulated and executed in public interest with a view to achieving additional capacity and delivery of quality public services at reasonable costs. These partnerships must ensure investment for supplementing scarce public resources while improving efficiencies. The government's current initiatives in the area of PPP are designed to achieve these objectives.

The following steps have been taken to promote private investment in infrastructure sector:

1. Setting up robust institutional structure for appraising and approving PPP projects

2. Developing standardised documents such as model concession agreements across infrastructure sectors

3. Increasing availability of finance by creating dedicated institutions and providing viability gap funding

The Committee on Infrastructure (CoI) was constituted in August 2004 under the Chairmanship of the Prime Minister, with the objectives of initiating policies that would 
ensure time-bound creation of world class infrastructure, delivering services matching international standards, developing structures that maximise the role of PPP and monitoring the progress of key infrastructure projects to ensure that targets are achieved.

In July 2009, the CoI was replaced by a Cabinet Committee on Infrastructure (CCI) under the Chairmanship of the Prime Minister. CCI reviews and approves policies and projects across infrastructure sectors. It considers and decides on financial, institutional and legal measures required to enhance investment in infrastructure sectors.

PPP Appraisal Committee and Empowered Institution: A Public-Private Partnership Appraisal Committee (PPPAC) consisting of the Secretary, Department of Economic Affairs, as Chairman, and Secretaries of the Planning Commission, Department of Expenditure, Department of Legal Affairs and the Administrative Department concerned, as Members was constituted for speedy approval of PPP projects. The project proposals are appraised by the Planning Commission and approved by the PPPAC. The Empowered Institution (EI) approves projects for providing Viability Gap Funding to the infrastructure projects at the State level.

Advisory Services: PPP projects are based on long-term contracts and may involve delegation of governmental authority such as for toll collection, besides enabling private control over monopolistic services. Implementation of PPP projects, therefore, requires appropriate advisory services in terms of preparation of project agreements, structuring of projects and so on. Planning Commission has operationalised a scheme for technical assistance to project authorities by providing consultants for projects. The Ministry of Finance has also created an India Infrastructure Project Development Fund (IIPDF) to provide loans for meeting development expenses, including the cost of engaging consultants for PPP projects.

Viability Gap Funding: The VGF Scheme was notified in 2006 to enhance the financial viability of competitively bid infrastructure projects, which are justified by economic returns, but do not pass the standard thresholds of financial returns. Under the scheme, grant assistance of up to 20 per cent of capital costs is provided by the Central Government to PPP projects undertaken by any Central Ministry, State Government, statutory entity or local body, thus leveraging budgetary resources to access a larger pool of private capital. An additional grant of up to 20 percent of project costs can be provided by the sponsoring Ministry, State Government or project authority.

Standardised Documents and Processes: The government has decided to formulate standard documents for bidding and award of PPP concessions. Adoption of a standardised framework ensures transparency in the allocation of risks, costs and obligations while minimising the potential for disputes and malfeasance.

The government has recently issued Guidelines for Monitoring of PPP Projects. 
These Guidelines seek to establish a two-tier institutional mechanism for monitoring of PPP projects that would ensure compliance of the contractual framework contained in the concession agreements with a view to safeguarding the interests of the public exchequer and the users.

Thus, private investment in infrastructure is being encouraged in an environment which ensures competition and transparency. Protection of public interest is being ensured by institutionalising the necessary frameworks and processes for due diligence, checks and balances. However, it is recognized that unless governance issues, such as those related to competition in service provision, collection of user charges, institutional capacity, regulation, and dispute resolution continue to be adequately addressed, mobilisation of sufficient resources for the requisite infrastructure investment may not be possible.

\subsubsection{Twelfth Five Year Plan (2012-17) on PPP in Infrastructure}

Underlining the role of PPP in infrastructure development, the Twelfth Plan observed, "Public Private Partnerships (PPPs) are increasingly becoming the preferred mode for construction and operation of infrastructure projects, both in developed and developing countries. PPPs are expected to augment resource availability as well as improve efficiency of infrastructure service delivery. Time and cost overrun in construction of PPP projects are also expected to be lower compared to traditional public procurement.

The adoption of standardized documents such as model concession agreements and bidding documents for award of PPP projects have streamlined and accelerated decisionmaking by agencies in a manner that is fair, transparent and competitive. This approach has contributed significantly to the recent strides in rolling out a large number of PPP projects in different sectors. India has 1,017 PPP projects accounting for an investment of Rs. 486,603 crore. According to the Private Participation in Infrastructure database of the World Bank, India is second only to China in terms of number of PPP projects and in terms of investments, it is second to Brazil.

Transport is the dominant PPP sector in India both by number of projects and investments, mainly due to the large number of road sector projects. Further efforts are needed to mainstream PPP in several areas such as power transmission and distribution, water supply and sewerage and railways where there is significant resource shortfall and also a need for efficient delivery of services. Similar efforts would also need to be initiated in social sectors, especially health and education.

The Government has also been emphasizing the need to explore the scope for PPP in the development of the social sectors like health and education. 
Some of the major PPP projects undertaken thus far are: Delhi, Mumbai, Hyderabad and Bengaluru airports; four ultra-mega power projects at Sasan (Madhya Pradesh), Mundra (Gujarat), Krishnapatnam (Andhra Pradesh) and Tilaiya (Jharkhand); container terminals at Mumbai, Chennai and Tuticorin ports; 15 concessions for operation of container trains; Jhajjar power transmission project in Haryana and 298 National and State Highway projects." (Planning Commission, 2011).

\subsection{Tax Incentives for Infrastructure Development}

\subsection{Rationale for Tax Incentives in Infrastructure Sector}

The magnitude of resources needed for the infrastructure sector is of such dimensions that the requisite investments would need to be funded eventually by raising resources from the domestic and international capital markets. In the initial stages, support from the financial institutions and commercial banks could be relied upon to a degree. However, there is clearly a limit to the extent of resources that could be accessed through the existing financial system.

In a liberalised economic regime, it is inevitable that all sectors would need to compete for capital. It is only those sectors that provide attractive rates of return that would eventually be successful in this resource-raising exercise. Projects in the infrastructure sector would need to compete for resources from the capital market and be perceived by investors as being as attractive as conventional manufacturing projects. It is, thus, desirable that such projects be brought to the centre stage of capital market flows to attract investments from a wider pool of lenders, including financial institutions, the corporate sector and in the medium term, retail investors.

Initial encouragement is needed from the Government to induce a sectoral flow of savings to the infrastructure sector. Once the initial clutch of projects of this genre is established successfully on commercial principles, fiscal benefits may no longer be needed to the same degree.

It can be demonstrated that the economic rate of returns from infrastructure projects is well in excess of the financial rate of returns. The higher economic rates of return stem from monetary as well as social factors including reduction in pollution levels, savings in time, and the ancillary economic activities that such projects generate.

The case for attracting FDI is significantly strengthened through the provision of an adequate level of infrastructure. There is thus adequate economic rationale for encouraging the sponsorship of infrastructure projects and to facilitate investments in this sector.

The commercialisation of infrastructure projects is typically formulated on the basis of recovery of investments through a system of user charges. Such user charges bear a 
direct relation to the specific benefits that the facility provides to the user. For example, a toll road would provide the user savings in terms of time, fuel, vehicular maintenance etc. The user would then compare the user charge to the benefits and savings realised. The level of user charges does not encompass the secondary and tertiary levels of economic benefits stemming from the implementation of the project and which flow to society at large. Typically, such benefits are a multiple of project cost. These externalities arise without government contributing to project expenditure.

To this extent, it can be argued that the provision of fiscal benefits is not a subsidy, but a contribution from government that is supported by benefits accruing from the externalities of the project. In the absence of such contribution, the private investment flows may not take place at all. Thus, such fiscal benefits have the effect of mobilising private resources in the financing of projects.

The fundamental premise of commercialisation is a shift of the burden of funding from government to a structure where public savings are channelised to create infrastructure facilities. Significant growth in the Indian capital market and the appetite of investors for financial assets received a fillip after specified fiscal incentives were provided by government for investments in the shares of newly promoted companies. Public savings were thus channelised towards the creation of productive capacities. A similar initiative is needed today from government to create a shift in savings towards investment in infrastructure.

Infrastructure projects in the targeted sectors are not readily amenable to attracting public savings. Typically these projects have a long gestation period and are not readily understood by retail and other investors. Hence, there is a need to position such investments as an attractive option vis-à-vis other competing opportunities. An investor today needs an inducement to shift a part of his portfolio from conventional projects to projects in the targeted sections. There is hence a need to consider the provision of specific fiscal benefits to infrastructure projects that are deemed to be of public interest.

Once a project is defined to an adequate degree, an array of fiscal benefits could be considered on a project-specific basis. The array of benefits could be defined under four generic heads:

- Tax-free status for the project entity.

- Benefits to the sponsor.

- Benefits to the wholesale investor.

- Benefits to the retail investor. 


\subsection{Income Tax Incentives under Section 80-IA}

Section 80-IA of Income Tax Act, 1961 provides for deduction from profits and gains of industrial undertakings/enterprises engaged in infrastructure development. The deduction is available to the following:

1. An enterprise owned by a company or consortium of companies or by an authority or a board or a corporation or any other statutory body, carrying on the business of: (i) developing, (ii) operating and maintaining, or (iii) developing, operating and maintaining, any infrastructure facility under an agreement with the Central/State Government or a local authority etc. which starts operating and maintaining the infrastructure facility on or after April 1, 1995. Infrastructure facility means the following: (a) a road including toll road, a bridge or a rail system, (b) a highway project including housing or other activities being an integral part of the highway project, (c) a water supply project, water treatment system, irrigation project, sanitation and sewerage system or solid waste management system, and (d) a port, airport, inland waterways or inland port or navigational channel in the sea.

2. An undertaking which starts providing telecommunication services (basic or cellular), including radio paging, domestic satellite services or network of trunking and electronic data interchange services, during April 1, 1995 to March 31, 2005.

3. (a) An undertaking which develops or develops and operates or maintains and operates an industrial park notified by the Ministry of Commerce and Industry, during April 1, 1997 to March 31, 2011. (b) An undertaking which develops, develops and operates, or maintains and operates a special economic zone notified by the Government for the period April 1, 1997 to March 31, 2006.

4. An undertaking set up in any part of India for the generation, or generation and distribution of power, which begins to generate power during April 1, 1993 to March 31, 2014.

5. An undertaking which starts transmission or distribution by laying a network of new transmission or distribution lines, during April 1, 1999 to March 31, 2014.

6. An undertaking which undertakes substantial renovation and modernization of the existing network of transmission or distribution lines, during April1, 2004 to March 31, 2014.

7. An undertaking owned by an Indian company (formed before November 30, 2005 and notified before December 31, 2005) and set up for reconstruction or revival of a power generating plant, which begins to generate or transmit or distribute power before March 31, 2011.

Amount of Deduction: The deduction is allowable for 10 consecutive assessment years (A.Ys) as under: 
(i) In the case of an undertaking providing telecommunication services

For the initial 5 A.Ys: 100 percent of the profits and gains

For the next 5 A.Ys: 30 percent of the profits and gains

(ii) In the case of other eligible undertakings and enterprises.

For 10 consecutive A.Ys: 100 percent of the profits and gains

The assessee may opt for any 10 consecutive years out of 15 years beginning with the year in which the undertaking starts the eligible activity.

In the case of an enterprise providing an infrastructure facility (except a port, airport, inland waterways, inland port or navigational channel in the sea), the assessee may opt for any 10 consecutive years out of 20 years beginning with the year in which it begins providing such infrastructure facility.

Experts have recommended several changes to be made in Section 80-IA which are crucial to the commercialisation of the country's infrastructure services.

1. The Section gives a restricted meaning to 'infrastructure facility' covering infrastructure relating to transport, such as surface transport, air, waterways and rail. Infrastructure, however, includes other services such as land area development, establishment of township, water and sewerage systems, social welfare like education and healthcare. These sectors have not been included in the definition. Therefore, the scope of infrastructure facility should be expanded to include all these sectors.

2. The Section also specifies that the infrastructure facility should be new. Accordingly, it may not include projects which involve remaking or expansion. Most infrastructure projects would involve acquisition of existing facility to meet the increased demands, e.g. a surface transport project could involve remaking the existing road and extending or converting two lanes into four lanes. Similarly, water and sewerage projects could involve taking over the existing distribution system or treatment facilities and building additional facilities to augment increased requirements. In most cases, it is necessary to capture revenues from existing facilities to make the expansion viable. Hence, the scope of definition should be extended to include projects involving expansion or remaking of existing facilities.

3. The Section requires the infrastructure facility to be owned by an enterprise. In many infrastructure projects, it may not be feasible to own all the facilities. As a financing strategy some of the equipment may be procured under a leasing or other financing arrangement. It is, therefore, necessary to clarify that the scope of this section extends to include cases where part of the infrastructure facility is procured under a lease or any other financing arrangement.

4. The benefits under the Section are available only to enterprises owned by a 
company - or a consortium of companies - incorporated in India. Given the nature of infrastructure projects, it would be necessary to have access to technological and financial participation from international sources. It is therefore necessary to extend the benefits to all enterprises including those where majority of shareholding is held by foreign companies.

5. In most infrastructure projects, it would be necessary to consider the grant of rights from the government to develop ancillary facilities such as land for building townships, developing adjacent areas or operating utilities like petrol pumps, restaurants etc. The current meaning of Section 80-IA defines tax holiday on profits derived from infrastructure business. Accordingly, the revenue authorities could argue that revenues or profits derived from such ancillary development are not eligible for tax holiday. However, in that case, the project would not be in a position to claim the tax holiday benefit on income purely derived from the user charges of infrastructure facilities because these revenues will not generate significant profits. A clarification should be provided in Section 80IA stating that the entire project income inclusive of income from any ancillary development will qualify for tax holiday benefit.

Extension of Section 80IA: Section 80IA of the Income Tax Act lists the Infrastructure facilities which are entitled to tax concessions. In his 2007-08 budget speech, the Union Finance Minister announced the extension of concessions under this section to (a) cross country natural gas distribution networks, including gas pipelines and storage facilities integrated to the network and (b) navigation channels in the sea.

\subsection{Other Tax Incentives}

Tax-free Bonds: In order to facilitate the creation of urban infrastructure, the Finance Minister in his 2007-08 budget speech allowed the issue of tax-free bonds through State Pooled Finance Entities formed for raising funds for a group of urban local bodies.

Incentives under Section 35-AC: To provide an incentive for funds to flow into the infrastructure sector on lines similar to those provided for other areas of national importance such as scientific research, investment in the share capital of SPVs undertaking infrastructure projects should be eligible for tax rebate. This incentive could be provided through an amendment to the provision of Section 35AC of the Income Tax Act 1961. Under Section 35AC, any expenditure by way of payments of any sum to public sector companies or a local authority or to any association or institution approved by a national committee for carrying out any eligible project or scheme for promoting social and economic welfare is allowed as deduction. Expenditure directly incurred on such projects or schemes is also allowed as deduction. Similar deduction should be 
provided in respect of expenditure on eligible infrastructure projects.

Further, deduction should also be provided in respect of expenditure incurred by companies on project development work. Projects eligible for benefits under Section $35 \mathrm{AC}$ could be defined as those where the financing is fully underwritten in a credible manner, or where the State Government or Central Government is a partner with a minimum equity stake of 10 percent.

\subsection{Incentives for Infrastructure by Reserve Bank of India (RBI)}

RBI has initiated a number of regulatory measures/concessions for infrastructure lending. Some of the important measures are:

a) Banks are allowed to enter into take out financing arrangement with IDFC/other Financial Institutions.

b) Banks are allowed to issue long-term bonds with a minimum maturity of 5 years to the extent of their exposure of residual maturity of more than 5 years to the infrastructure sector.

c) Banks are allowed a relaxation of 5 percent in the case of single borrower limit and 10 percent in the case of group borrower limit provided the additional credit exposure is on account of extension of credit to infrastructure projects.

d) Banks are permitted to invest in unrated bonds of companies engaged in infrastructure activities within the ceiling of 10 percent for unlisted non-SLR securities.

e) The promoters' shares in the SPV of an infrastructure project pledged to the lending bank are permitted to be excluded from the banks' capital market exposure.

f) Subject to certain conditions, banks are permitted to extend finance for funding promoter's equity in cases where the proposal involves acquisition of share in an existing company engaged in implementing or operating an infrastructure project in India.

g) Interest rate futures have been reintroduced which could aid banks in managing their interest rate risk more efficiently.

h) The existing capital adequacy treatment of take-out financing is in conformity with the capital adequacy treatment of forward asset purchases under both Basel I and Basel II. The issue was reconsidered and it was proposed to allow banks to build up capital for take-out exposures in a phased manner.

i) A new category of NBFCs as 'infrastructure NBFCs', has been introduced. These include entities which hold minimum of 75 percent of their total assets for financing infrastructure projects. The risk weight for banks' exposure to these NBFCs would be related to their credit rating.

j) In order to develop the corporate bond market, Clearing and Settlement of OTC 
Trades in Corporate Bonds, on a DVP basis has been operationalised. Draft guidelines for introduction of repos in corporate bonds have been issued. An internal group in the Reserve Bank has been set up for introduction of plain vanilla OTC single-name CDS for corporate bonds for resident entities which would be subject to subject to appropriate safeguards.

(Source: Reserve Bank of India, Financial Stability Report, March 2010, p. 41.)

\subsection{Foreign Direct Investment (FDI) in Infrastructure}

India has one of the most transparent and liberal FDI regimes among the emerging and developing economies. By FDI regime is meant those restrictions that apply to foreign nationals and entities but not to Indian nationals and Indian owned entities. The differential treatment is limited to a few entry rules, spelling out the proportion of equity that the foreign entrant can hold in an Indian (registered) company or business. There are a few banned sectors (like lotteries and gaming and legal services) and some sectors with limits on foreign equity proportion. The entry rules are clear and well-defined and equity limits for foreign investment in selected sectors such as telecom quite explicit and wellknown.

The initial policy stimulus to FDI in India came in July 1991 when the new industrial policy provided, inter alia, automatic approval for projects with foreign equity participation up to 51 percent in high priority areas. In recent years, the Government has initiated the second generation reforms under which measures have been taken to further facilitate and broaden the base of FDI in India. The policy for FDI allows freedom of location, choice of technology, repatriation of capital and dividends. As a result of these measures, there has been a strong surge of international interest in the Indian economy. The rate at which foreign direct investment inflow has grown during the postliberalisation period is a clear indication that India is fast emerging as an attractive destination for overseas investors.

As part of the economic reforms programme, policy and procedures governing foreign investment and technology transfer have been significantly simplified and streamlined. Presently, foreign investment is freely allowed in all sectors including the services sector except in cases where there are sectoral ceilings.

\subsection{Caps and conditions on FDI in Infrastructure sector}

Investments can be made by non-residents in the capital of a resident entity only to the extent of the percentage of the total capital as specified in the FDI policy. Investments by non-residents can be permitted in the capital of a resident entity in 
certain sectors/activity with entry conditions. Such conditions may include norms for minimum capitalization, lock-in period etc. Besides the entry conditions on foreign investment, the investment/investors are required to comply with all relevant sectoral laws, regulations, rules, security conditions, and state/ local laws/regulations.

In the sectors/activities mentioned in Table 1, FDI up to the limits indicated against each sector/activity is allowed, subject to applicable laws/regulations, security and other conditions.

\subsection{Regulatory framework}

In recent years, independent regulatory authorities have been established in the power, telecom, and civil aviation sectors. Tariffs in the port sector are also fixed by an independent authority. These authorities discharge numerous responsibilities, which were earlier in the domain of the government. For initiating further improvements in the regulatory structures and practices, Regulatory Reforms Bill is under consideration of the Government.

Table 1: Select Infrastructure Activities in which FDI is allowed up to the limits indicated

\begin{tabular}{|c|c|c|}
\hline Sector/Activity & $\begin{array}{c}\text { Percent of FDI } \\
\text { Cap/Equity }\end{array}$ & $\begin{array}{l}\text { Entry } \\
\text { Route }\end{array}$ \\
\hline \multicolumn{3}{|l|}{ MINING } \\
\hline $\begin{array}{l}\text { Mining and exploration of metal and non- } \\
\text { metal ores including diamond, gold, silver and } \\
\text { precious ores but excluding titanium bearing } \\
\text { minerals and its ores; subject to the Mines and } \\
\text { Minerals (Development and Regulation) Act, } \\
1957 \text {. }\end{array}$ & 100 & Automatic \\
\hline \multicolumn{3}{|l|}{ Coal and Lignite } \\
\hline $\begin{array}{l}\text { Coal and Lignite mining for captive } \\
\text { consumption by power projects, iron and steel } \\
\text { and cement units and other eligible activities } \\
\text { permitted under and subject to provisions of } \\
\text { Coal Mines (Nationalization) Act, } 1973 \text {. }\end{array}$ & 100 & Automatic \\
\hline \multicolumn{3}{|l|}{ Petroleum and Natural Gas } \\
\hline $\begin{array}{l}\text { Exploration activities of oil and natural gas } \\
\text { fields, infrastructure related to marketing of } \\
\text { petroleum products and natural gas, marketing }\end{array}$ & 100 & Automatic \\
\hline
\end{tabular}




\begin{tabular}{|c|c|c|}
\hline \multicolumn{3}{|l|}{$\begin{array}{l}\text { of natural gas and petroleum products, } \\
\text { petroleum product pipelines, natural } \\
\text { gas/pipelines, LNG regasification } \\
\text { infrastructure, market study and formulation } \\
\text { and petroleum refining in the private sector, } \\
\text { subject to the existing sectoral policy and } \\
\text { regulatory framework in the oil marketing } \\
\text { sector and the policy of the Government on } \\
\text { private participation in exploration of oil and } \\
\text { the discovered fields of national oil companies }\end{array}$} \\
\hline $\begin{array}{l}\text { Petroleum refining by the Public Sector } \\
\text { Undertakings (PSU), without any } \\
\text { disinvestment or dilution of domestic equity } \\
\text { in the existing PSUs. }\end{array}$ & 49 & Government \\
\hline \multicolumn{3}{|l|}{ Civil Aviation } \\
\hline \multicolumn{3}{|l|}{ Airports } \\
\hline Greenfield projects & 100 & Automatic \\
\hline Existing projects & 100 & $\begin{array}{l}\text { Automatic } \\
\text { up to } 74 \\
\text { percent. } \\
\text { Government } \\
\text { route } \\
\text { beyond } 74 \\
\text { percent }\end{array}$ \\
\hline \multicolumn{3}{|l|}{ Air Transport Services } \\
\hline $\begin{array}{l}\text { Air transport services would include } \\
\text { domestic scheduled passenger airlines; } \\
\text { Non-scheduled air transport services, } \\
\text { helicopter and seaplane services. } \\
\text { No foreign airlines would be allowed to } \\
\text { participate directly or indirectly in the } \\
\text { equity of an air transport undertaking } \\
\text { engaged in operating scheduled and non- } \\
\text { scheduled air transport services except } \\
\text { Cargo airlines. } \\
\text { Foreign airlines are allowed to participate } \\
\text { in the equity of companies operating } \\
\text { cargo airlines, helicopter and seaplane } \\
\text { services. }\end{array}$ & & \\
\hline Scheduled air transport service/domestic & 49 (FDI) & Automatic \\
\hline
\end{tabular}


58 | VISION: Journal of Indian Taxation, Volume 2, Issue 2

\begin{tabular}{|c|c|c|}
\hline scheduled passenger airline & 100 (for NRIs) & \\
\hline Non-scheduled air transport service & $\begin{array}{c}74 \text { (FDI) } \\
100 \text { (for NRIs) }\end{array}$ & $\begin{array}{c}\text { Automatic } \\
\text { up to } 49 \\
\text { percent. } \\
\text { Government } \\
\text { route } \\
\text { beyond } 49 \\
\text { and up to } 74 \\
\text { percent }\end{array}$ \\
\hline $\begin{array}{l}\text { Helicopter services/seaplane services } \\
\text { requiring DGCA approval }\end{array}$ & 100 & Automatic \\
\hline Other Services under Civil Aviation Sector & & \\
\hline $\begin{array}{l}\text { Ground Handling Services subject to sectoral } \\
\text { regulations and security clearance }\end{array}$ & $\begin{array}{c}74 \text { (FDI) } \\
100 \text { (for NRIs) }\end{array}$ & $\begin{array}{l}\text { Automatic } \\
\text { up to } 49 . \\
\text { Government } \\
\text { route } \\
\text { beyond } 49 \\
\text { and up to } 74 \\
\text { percent }\end{array}$ \\
\hline $\begin{array}{l}\text { Maintenance and repair organizations, flying } \\
\text { training institutes and technical training } \\
\text { institutions }\end{array}$ & 100 & Automatic \\
\hline $\begin{array}{l}\text { Courier services for carrying packages, } \\
\text { parcels and other items which do not come } \\
\text { within the ambit of the Indian Post Office Act, } \\
1898 \text { and excluding the activity relating to the } \\
\text { distribution of letters. }\end{array}$ & 100 & Government \\
\hline \multicolumn{3}{|l|}{$\begin{array}{l}\text { Construction Development: Townships, } \\
\text { Housing, Built-up Infrastructure }\end{array}$} \\
\hline $\begin{array}{l}\text { Townships, housing, built-up infrastructure } \\
\text { and construction-development projects (which } \\
\text { would include, but not be restricted to } \\
\text { housing, commercial premises, hotels, resorts, } \\
\text { hospitals, educational institutions, recreational } \\
\text { facilities, city and regional level } \\
\text { infrastructure) }\end{array}$ & 100 & Automatic \\
\hline Industrial Parks - new and existing & 100 & Automatic \\
\hline \multicolumn{3}{|l|}{ Satellites: Establishment and Operation } \\
\hline $\begin{array}{l}\text { Satellites: Establishment and operation, } \\
\text { subject to the sectoral guidelines of }\end{array}$ & 74 & Government \\
\hline
\end{tabular}




\begin{tabular}{|c|c|c|}
\hline \multicolumn{3}{|l|}{ Department of Space/ISRO } \\
\hline $\begin{array}{l}\text { Telecom Services } \\
\text { Investment caps and other conditions for } \\
\text { specified services are given below. However, } \\
\text { licensing and security requirements notified } \\
\text { by the Department of Telecommunications } \\
\text { will need to be complied with for all services. }\end{array}$ & & \\
\hline Telecom services & 74 & $\begin{array}{l}\text { Automatic } \\
\text { up to } 49 \\
\text { percent. } \\
\text { Government } \\
\text { route } \\
\text { beyond } 49 \\
\text { and up to } 74 \\
\text { percent }\end{array}$ \\
\hline $\begin{array}{l}\text { - ISP with gateways } \\
\text { - } \quad \text { ISP`s not providing gateways i.e. without } \\
\text { gate-ways (both for satellite and marine } \\
\text { cables) } \\
\text { Note: The new guidelines of August } 24,2007 \\
\text { Department of Telecommunications provide } \\
\text { for new ISP licenses with FDI up to } 74 \\
\text { percent. } \\
\text { - } \quad \text { Radio paging } \\
\text { - } \quad \text { End-to-End bandwidth }\end{array}$ & 74 & $\begin{array}{l}\text { Automatic } \\
\text { up to } 49 \\
\text { percent. } \\
\text { Government } \\
\text { route } \\
\text { beyond } 49 \\
\text { and up to } 74 \\
\text { percent }\end{array}$ \\
\hline $\begin{array}{l}\text { - Infrastructure provider providing dark } \\
\text { fibre, right of way, duct space, tower (IP } \\
\text { Category I) } \\
\text { - } \quad \text { Electronic Mail } \\
\text { - Voice Mail } \\
\text { Note: Investment in all the above activities is } \\
\text { subject to the conditions that such companies } \\
\text { will divest } 26 \text { percent of their equity in favour } \\
\text { of Indian public in } 5 \text { years, if these companies } \\
\text { are listed in other parts of the world. }\end{array}$ & 100 & $\begin{array}{l}\text { Automatic } \\
\text { up to } 49 \\
\text { percent. } \\
\text { Government } \\
\text { route } \\
\text { beyond } 49 \\
\text { percent }\end{array}$ \\
\hline
\end{tabular}

Source: Government of India, Ministry of Commerce and Industry, Department of Industrial Policy and Promotion, Consolidated FDI Policy, (Effective from October 1, 2011). 


\subsection{Conclusion}

To sum up, infrastructure provides the basic support system for other sectors of the economy expanding capabilities everywhere. A distinguishing characteristic of infrastructure is that where imports can meet the gap between demand and supply, deficiencies in infrastructure cannot be made good through imports. Infrastructure requirements can only be met through development of the relevant infrastructure capacity in the domestic economy. Furthermore, Good quality infrastructure is important not only for faster growth but also to ensure that growth is inclusive. Small businesses spread throughout the country need access to good quality and reliable infrastructure services to compete effectively.

Large enterprises can often develop their own infrastructure as they often do with captive power, and being large can even locate themselves ab initio where other infrastructure is better, that is, nearer ports and near transport hubs. Small enterprises on the other hand are dispersed across the country, and have to rely on the general infrastructure available. Their ability to compete successfully, which is critical for growth to be employment generating and inclusive, depends upon the quality of this infrastructure.

Government of India policy initiatives have served to open the Indian economy and achieve a higher degree of integration with the world economy. A focused effort is underway to render Indian firms globally competitive, ease the barriers of entry and provide an impetus to exports. To attain these goals, India requires to rapidly demonstrate its competitive advantage in terms of a deep domestic market with purchasing power, affordable level of wages, labour productivity, natural resources, and most importantly infrastructure availability. It is therefore essential to accelerate investment in this sector.

A conscious policy has now been adopted by the government to minimise any drain on the exchequer through subsidies. To that extent, and as a generic principle, it would be appropriate to implement infrastructure projects without the provision of any fiscal benefits to the extent feasible. The problems of transportation and communications, roads, railways, airports, telecom, ports, the postal system, electricity transmission and distribution have been a prominent focus of economic policy since early 1990s.

The thrust of infrastructure policy has been to create a sound regulatory framework. Private firms would operate in this regulatory environment, and produce infrastructure services. The role for regulation is to protect the interests of consumers, obtain conditions of competition, and foster the institutional framework. In areas like rural infrastructure, where cost recovery is innately difficult, there is a greater role for government 
to foster infrastructure provision even if it is not directly profitable.

Typically, power and telecom projects are well understood by promoters, financial institutions, and investors in the capital markets. Significant efforts have been made by the government to put in place a policy framework for these sectors. In addition, operating guidelines are also in place to implement projects in these sectors on an independent basis.

\section{References}

Government of India. (2000-01). Economic Survey.

Government of India. (2011). Planning Commission, An Approach to the Twelfth Five Year Plan, October. 